\begin{abstract}
Iranica
Abstracta Iranica Revue bibliographique pour le domaine irano-aryen

Volume 32-33 | 2013

Comptes rendus des publications de 2009-2010
\end{abstract}

\title{
Devin Stewart. Three polemic exchanges at the Safavid court
}

\section{Mathieu Terrier}

\section{(2) OpenEdition}

1 Journals

\section{Édition électronique}

URL : http://journals.openedition.org/abstractairanica/40308

DOI : 10.4000/abstractairanica.40308

ISSN : 1961-960X

Éditeur :

CNRS (UMR 7528 Mondes iraniens et indiens), Éditions de l'IFRI

\section{Édition imprimée}

Date de publication : 1 décembre 2013

ISSN : 0240-8910

\section{Référence électronique}

Mathieu Terrier, "Devin Stewart. Three polemic exchanges at the Safavid court », Abstracta Iranica [En ligne], Volume 32-33 | 2013, document 368, mis en ligne le 01 juillet 2016, consulté le 26 septembre 2020. URL : http://journals.openedition.org/abstractairanica/40308; DOI : https://doi.org/10.4000/ abstractairanica.40308

Ce document a été généré automatiquement le 26 septembre 2020.

Tous droits réservés 


\title{
Devin Stewart. Three polemic exchanges at the Safavid court
}

\author{
Mathieu Terrier
}




\section{RÉFÉRENCE}

Devin Stewart. "Three polemic exchanges at the Safavid court », in : Mohammad Ali Amir-Moezzi, Meir M. Bar-Asher, Simon Hopkins, éds., Le shīisme imāmite quarante ans après. Hommage à Etan Kohlberg. Turnhout, Brepols, 2009, p. 397-415.

Cet article illustre le rôle des savants chiites originaires du Jabāl 'Āmil, au Liban, dans la politique religieuse de la dynastie safavide, à travers trois échanges polémiques ayant opposé certains de ces savants à des émissaires de l'empire ottoman sunnite. Dans le premier épisode, Ḥusayn b. 'Abd al-Ṣamad al-'Āmilī (m. 984/1576), immigré en Iran en 961/1554 et autorité juridique sous le règne de Shah Ṭahmāsb (r. 930-984/1524-1576), défend les positions traditionnelles chiites concernant les droits de la Famille du Prophète, lors d'une crise politique majeure entre les deux royaumes. Le deuxième échange voit Bahā' al-Dīn al-'Āmilī (m. 1030/1621), le fils aîné de Ḥusayn b. 'Abd

al-Șamad, actif sous le règne de Shah 'Abbās I (996-1038/1587-1629), contrer les accusations sunnites au sujet de l'interdiction faite par les docteurs chiites de consommer de la viande sacrifiée par des Juifs ou des Chrétiens. La troisième confrontation oppose le jeune frère de Bahā' al-Dīn, Abd al-Ṣamad, et un émissaire ottoman à la cour de Shah 'Abbās, au sujet des mérites respectifs des ulamā' des deux États. Les deux derniers échanges auraient eu lieu au cours de la même ambassade, en 1020/1611. Ils témoignent d'un même climat de détente dans les relations entre l'Iran safavide chiite et l'empire ottoman sunnite, où les sujets de désaccord fondamental laissent place à des considérations pragmatiques. L'article présente l'intérêt d'illustrer par des cas précis le rôle des «intellectuels organiques", selon l'expression d'A. Gramsci, en Iran safavide.

\section{AUTEURS}

\section{MATHIEU TERRIER}

Paris 